$\begin{array}{lllllllll}\text { A C T A } & \text { C H E M I A } & \text { S C A N D I N A V I C A } & 17 & (1963) & \text { S 246-S } 249\end{array}$

\title{
Fluorometric Analysis of Enzyme-Substrate Complex Formation
}

\author{
KUNIO YAGI and TAKAYUKI OZAWA \\ Institute of Biochemistry, Faculty of Medicine, University of Nagoya, \\ Nagoya, Japan
}

\begin{abstract}
Theorell's method for recording fluorescence was applied to follow the change in fluorescence intensity of $\mathrm{D}$-amino acid oxidase mixed with the substrate. Bringing the conditions for the enzyme catalysis apart from their optima, it was demonstrated that a lag time $\left(t_{1}\right)$ appears before the rapid decrease in the fluorescence intensity $\left(t_{2}\right), t_{1}$ may correspond to the time for the complex formation between the enzyme and the substrate, and $t_{2}$ to that for the enzyme in the complex to convert into its semiquinoid form. As the functions of $t_{1}$ and $t_{2}$ obey the equation of Arrhenius, it can be postulated that the enzyme passes through two transitionary activated complexes to reach its semiquinoid form. Similarity of the $\mathrm{pH}-1 / t_{1}$ curve to the $\mathrm{pH}$-activity curve indicates that $1 / t_{1}$ determines the reaction rate.
\end{abstract}

A ccording to Michaelis and Menten ${ }^{1}$, enzyme catalysis involves two steps, viz. $A_{(1)}$ the formation of a complex of enzyme (E) and substrate (S) followed by (2) its breakdown to enzyme and product of the reaction,

$$
\mathrm{E}+\mathrm{S} \underset{k_{-1}}{\stackrel{k_{+1}}{\rightleftharpoons}} \mathrm{E} \cdot \mathrm{S} \stackrel{k_{+2}}{\rightarrow} \mathrm{E}+\mathrm{P}
$$

and the rate of the second step determines the rate of the reaction.

In the series of our study on $\mathrm{D}$-amino acid oxidase (D-amino acid : $\mathrm{O}_{2}$ oxidoreductase (deaminating) EC 1.4.3.3), we succeeded in crystallizing a complex of the semiquinoid form of the holo-enzyme and the partially modified substrate as an intermediate complex $\left(\mathrm{E}^{\prime} \cdot \mathrm{S}^{\prime}\right)$ during the enzymic reaction ${ }^{2,3}$. A complex of the holo-enzyme and a reaction product, pyruvate, $(\mathrm{E} \cdot \mathrm{P})$ was also isolated in the crystalline form ${ }^{4}$. Besides these intermediate complexes, it may be supposed that there exists a complex of the holo-enzyme and the substrate without modification $(E \cdot S)$. Thus, the minimum number of steps involved in the reaction of the enzyme catalysis could be represented as follows: 


$$
\mathrm{E}+\mathrm{S} \underset{k_{-1}}{\stackrel{k_{+1}}{\rightleftharpoons}} \mathrm{E} \cdot \mathrm{S} \underset{k_{-2}}{\stackrel{k_{+2}}{\rightleftharpoons}} \mathrm{E}^{\prime} \cdot \mathrm{S}^{\prime} \underset{k_{-3}}{\stackrel{k_{+3}}{\rightleftharpoons}} \mathrm{E} \cdot \mathrm{P} \underset{k_{-4}}{\stackrel{k_{+4}}{\rightleftharpoons}} \mathrm{E}+\mathrm{P}
$$

Now, we intended to study the E.S formation. For this purpose, we measured the dynamic change in fluorescence intensity of the holo-enzyme when mixed with the substrate.

\section{MATERIALS AND METHODS}

D-Amino acid oxidase holo-enzyme was prepared ${ }^{6}$ as follows: The crystal suspension of the Michaelis complex $\left(\mathrm{E}^{\prime} \cdot \mathrm{S}^{\prime}\right)$ was gradually oxidized by dialyzing against distilled water at $5^{\circ} \mathrm{C}$ overnight. The yellow-coloured holo-enzyme crystals were collected by centrifugation and dissolved in distilled water.

The substrate, D-alanine, was obtained from Nutritional Biochemicals Corporation.

The recording fluorometer was essentially the same as that of Theorell and Nygaard ${ }^{5}$. 1.5 $\mathrm{ml}$ of the solution of the holo-enzyme crystals $(20 \mu \mathrm{M})$ mixed with an equal volume of pyrophosphate buffer $(0.03 \mathrm{M})$ was transferred to a cuvette $(10 \times 10 \mathrm{~mm})$ in the fluorometer. Under anaerobic condition, $0.1 \mathrm{ml}$ of $\mathrm{D}$-alanine solution was mixed and the change in fluorescence intensity of the holo-enzyme recorded (chart speed, $6 \mathrm{~cm}$ per min; response time, $0.3 \mathrm{sec}$ ).

\section{RESULTS}

Dynamic change in fluorescence intensity. At the optimum $\mathrm{pH}, 8.3$, for the enzyme catalysis, the fluorescence intensity of the enzyme began to drop immediately after mixing with an excess of substrate, as shown by Curve I in Fig. 1. However, it was found that a lag time appeared when the substrate concentration was decreased (Curve II and III), and when the $\mathrm{pH}$ (Curve IV), or the temperature (Curve V) was lowered. As can be seen in these curves, the lag time $\left(t_{1}\right)$ could be easily distinguished from the time of rapid decrease in fluorescence intensity $\left(t_{2}\right)$.

At the same time, the change in the absorbancy of the holo-enzyme at $453 \mathrm{~m} \mu$ $\left(\mathrm{A}_{453}\right)^{7}$ and that of the semiquinoid form of the enzyme at $550 \mathrm{~m} \mu\left(\mathrm{A}_{550}\right)^{8}$ were

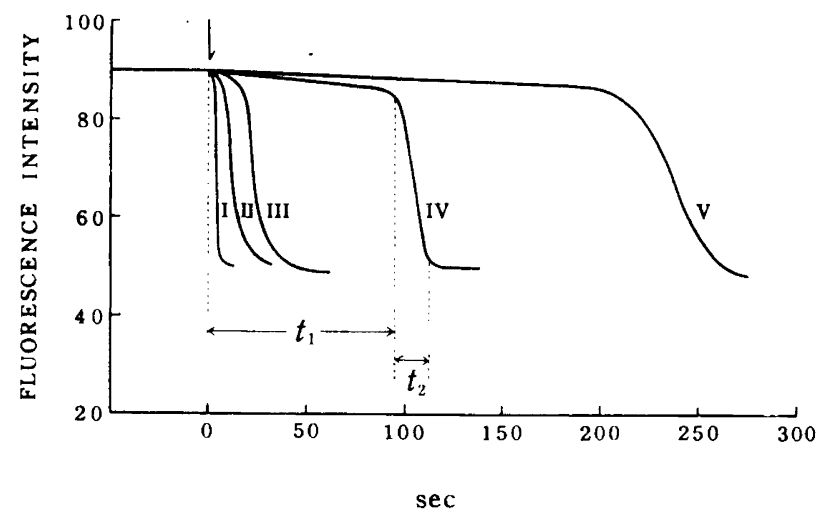

Fig. 1. Dynamic change of the relative fluorescence intensity of the holo-enzyme with added substrate. Holo-enzyme was $10 \mu \mathrm{M}$ in all cases. Curve I: D-alanine $16 \mathrm{mM}, \mathrm{pH} 8.3,20^{\circ} \mathrm{C}$; Curve II: D-alanine $0.5 \mathrm{mM}, \mathrm{pH} 8.3,20^{\circ} \mathrm{C}$; Curve III: D-alanine $0.2 \mathrm{mM}, \mathrm{pH} 8.3,20^{\circ} \mathrm{C}$; Curve IV: D-alanine $0.2 \mathrm{mM}, \mathrm{pH} 7.2,20^{\circ} \mathrm{C}$; Curve V: D-alanine $0.2 \mathrm{mM}, \mathrm{pH} 7.2,15^{\circ} \mathrm{C}$. The arrow shows the addition of the substrate. 


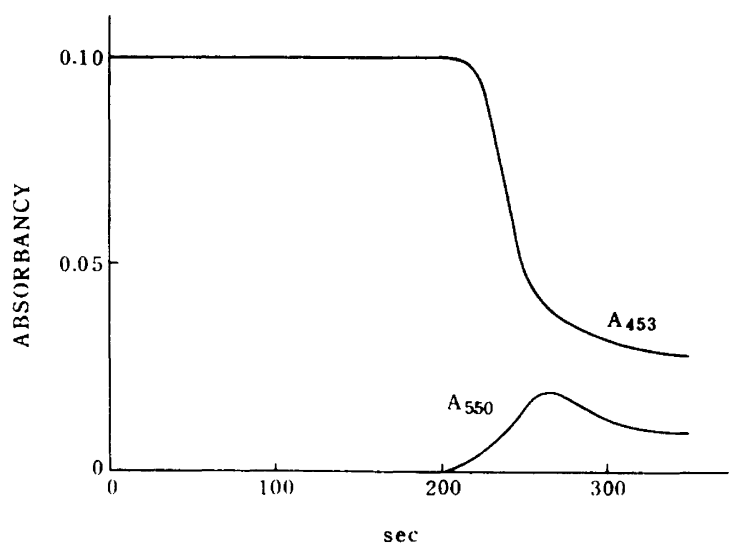

Fig. 2. Dynamic change of the absorbancy of the holo-enzyme. Absorbancies at $453 \mathrm{~m} \mu\left(\mathrm{A}_{453}\right)$ and at $550 \mathrm{~m} \mu\left(\mathrm{A}_{550}\right)$ of the holo-enzyme, $10 \mu \mathrm{M}$, were recorded after addition of the substrate, $0.2 \mathrm{mM}$, at $\mathrm{pH} 7.2,15^{\circ} \mathrm{C}$.

traced on a recording spectrophotometer. The dynamic changes in absorbancies of the sample of Curve V in Fig. 1 are shown in Fig. 2. The curves show that the decrease in fluorescence of the enzyme was accompanied by a decrease of $\mathrm{A}_{453}$ and an increase of $\mathrm{A}_{550}$. This indicates that $t_{2}$ corresponds to the time for the enzyme in the complex to pass into its semiquinoid form.

$p H$-dependence of $t_{1}$ and $t_{2} . t_{1}$ and $t_{2}$ were measured with a constant substrate concentration $(0.2 \mathrm{mM})$ and temperature $\left(18^{\circ} \mathrm{C}\right)$ at different $\mathrm{pH}$.

The plots of $t_{1}$ and $t_{2}$ against $\mathrm{pH}$ are shown in Fig. 3 . As seen from the curves, the $\mathrm{pH}$-dependence of $t_{1}$ is remarkable, whereas $t_{2}$ shows a very small $\mathrm{pH}$-dependence. It should be noted that the shape of the plot of $1 / t_{1}$ against $\mathrm{pH}$ is nearly the same as that of the $\mathrm{pH}$-activity curve of the enzyme ${ }^{9}$.

Temperature-dependence of $t_{1}$ and $t_{2}$. The relation between temperature and $t_{1}$ or $t_{2}$ was examined by measuring $t_{1}$ and $t_{2}$ at constant $\mathrm{pH}$ and at different temperatures.

It was found that $\log 1 / t_{1}$ or $\log 1 / t_{2}$ is directly proportional to negative reciprocal of the absolute temperature at any $\mathrm{pH}$ measured. Two typical results are shown in Fig. 4.

\section{DISCUSSION}

The fluorometric and spectrophotometric results (Figs. 1 and 2) show that $t_{2}$ is the time required for the second step of the enzyme catalysis, viz. $\mathrm{E} \cdot \mathrm{S} \rightleftharpoons \mathrm{E}^{\prime} \cdot \mathrm{S}^{\prime}$, and $t_{1}$ for the first step, viz. $\mathrm{E}+\mathrm{S} \rightleftharpoons \mathrm{E} \cdot \mathrm{S}$. Under optimum conditions, the lag time, $t_{1}$, is masked by the second step and can not be demonstrated.

The $\mathrm{pH}$-dependence of $t_{1}$ shown in Fig. 3 presents an evidence that the enzyme combines with the substrate through some ionized residues. As it is considered that the plot of $1 / t_{1}$ against $\mathrm{pH}$ is essentially a titration curve of $\mathrm{E} \cdot \mathrm{S}$, the $\mathrm{p} K_{\mathrm{a}}=8.1$ suggests that some weak acidic groups are involved in $\mathrm{E} \cdot \mathrm{S}$ formation. It is also noted that the shape of the $\mathrm{pH}-1 / t_{1}$ curve is similar to that of the $\mathrm{pH}$-activity curve ${ }^{9}$. 


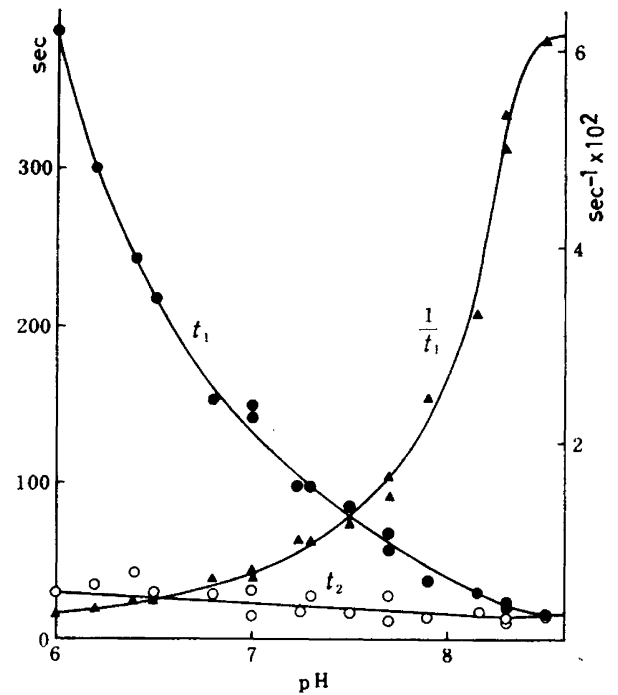

Fig. 3. Plots of $t_{1}, t_{2}$ and $1 / t_{1}$ against $\mathrm{pH}$. $t_{1}$ and $t_{2}$ were measured by mixing the holoenzyme, $10 \mu \mathrm{M}$, with $\mathrm{D}$-alanine, $0.2 \mathrm{mM}$, at $18^{\circ} \mathrm{C}$. The left ordinate scale is for $t_{1}$ and $t_{2}$, and the right for $1 / t_{1}$.

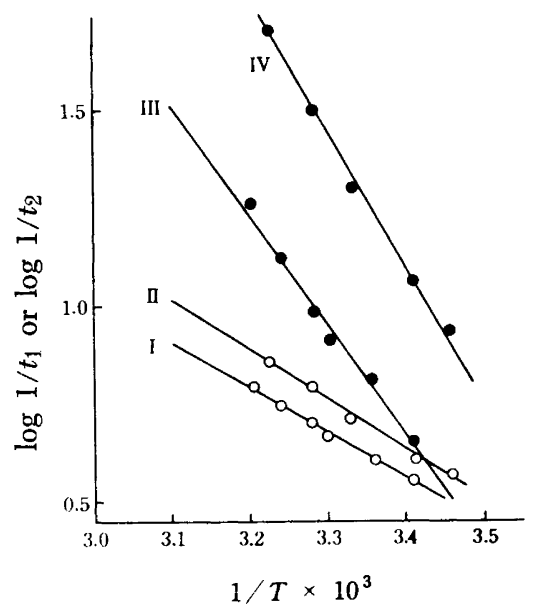

Fig. 4. Plots of $\log 1 / t_{1}$ and $\log 1 / t_{2}$ against $1 / T\left(\mathrm{~T}\right.$ in $\left.{ }^{\circ} \mathrm{K}\right) . t_{1}$ and $t_{2}$ were measured by mixing the holo-enzyme, $10 \mu \mathrm{M}$, with $\mathrm{D}$ alanine, $0.2 \mathrm{mM}$. Curve IV: $2.5+\log 1 / t_{1}$ at $\mathrm{pH} 7.9$, Curve III: $2.5+\log 1 / t_{1}$ at $\mathrm{pH}$ 7.0, Curve II: $1.8+\log 1 / t_{2}$ at $\mathrm{pH} 7.9$, Curve I: $1.8+\log 1 / t_{2}$ at $\mathrm{pH} 7.0$.

On the assumption that both the rate constant of the first step $\left(k_{+1}\right)$ and that of the second step $\left(k_{+2}\right)$ in Reaction (2) are proportional to $1 / t_{1}$ and $1 / t_{2}$, respectively, it was demonstrated that both $k_{+1}$ and $k_{+2}$ obey the equation of Arrhenius,

$$
\ln k=-\mathrm{E}_{\mathrm{a}} / R T+\ln \mathrm{A}
$$

and it can thus be postulated that the enzyme passes through two transitionary activated complexes to reach $\mathrm{E}^{\prime} \cdot \mathrm{S}^{\prime}$.

From these results, it is considered that the $\mathrm{E} \cdot \mathrm{S}$ formation is an important factor in determining the rate of the enzymic reaction.

\section{REFERENCES}

1. Michaelis, L. and Menten, M. L. Biochem. Z. 49 (1913) 333.

2. Yagi, K. and Ozawa, T. Biochim. Biophys. Acta 60 (1962) 200.

3. Yagi, K. and Ozawa, 'T. Biochim. Biophys. Acta. In press.

4. Yagi, K. and Ozawa, 'T. Unpublished results.

5. Theorell, H. and Nygaard, A. P. Acta Chem. Scand. 8 (1954) 877.

6. Yagi, K. and Ozawa, T. Unpublished results.

7. Yagi, K. and Ozawa, T. Biochim. Biophys. Acta 56 (1962) 413.

8. Yagi, K. and Ozawa, T. Biochim. Biophys. Acta 67 (1963) 685.

9. Yagi, K. and Ozawa, T. Biochim. Biophys. Acta 56 (1962) 420.

Received March 30, 1963. 